\title{
The Relative Humidity Effect Of The Reactants Flows Into The Cell To Increase PEM Fuel Cell Performance
}

\author{
Mulyazmi $^{1}$, W. R W Daud ${ }^{2}$,Silvi Octavia ${ }^{1}$, Maria Ulfah $^{1}$ \\ ${ }^{1}$ Department of Chemical Engineering, University of Bung Hatta Padang, West Sumatera, Indonesia \\ ${ }^{2}$ Fuel Cell Institute, Universiti Kebangsaan Malaysia, 43600 UKM Bangi, Selangor, Darul Ehsan, Malaysia
}

\begin{abstract}
Design of the Proton Exchange Membrane (PEM) fuel cell system is still developed and improved to achieve performance and efficiency optimal. Improvement of PEM fuel cell performance can be achieved by knowing the effect of system parameters based on thermodynamics on voltage and current density. Many parameters affect the performance of PEM fuel cell, one of which is the relative humidity of the reactants that flow in on the anode and cathode sides. The results of this study show that the increase in relative humidity value on the cathode side (RHC) causes a significant increase in current density value when compared to the increase of relative humidity value on the anode side (RHA). The performance of single cells with high values is found in $\mathrm{RHC}$ is from $70 \%$ to $90 \%$. The maximum current density generated at $\mathrm{RHA}$ is $70 \%$ and $\mathrm{RHC}$ is $90 \%$ with PEM operating tem perature of $363 \mathrm{~K}$ and pressure of $1 \mathrm{~atm}$
\end{abstract}

\section{Introduction}

Fuel cells are electro chemical devices that convert chemical energy from fuel (hydrogen) and oxidant (oxygen or air) directly into electrical energy and thermal energy, producing water as a by product [1-3]. One type of fuel cell is the PEM fuel cell, which can be operated at low temperatures to produce electrical energy. Developing the system performance of PEM fuel cells requires a suitable design and appropriate technology. The main purpose is to achieve optimal performance and obtain a low-cost PEM fuel cell system.

Many parameters in the PEM fuel cell system are associated with other parameters in the system. These parameters consist of the operating conditions, the design of the membrane electrolyte as sembly (MEA) and the stack PEM fuel cell system [4-5]. In the case of the PEM fuel cells, the system is defined as a group of objects or materials that are integrated and operated together. The performance of the PEM fuel cells is evaluated in the form of the voltage generated, the power density and the efficiency. The optimal performance of the cells is influenced by many internal and external factors, such as the fuel cell design and assembly, the degradation of materials, the operating conditions and the impurities or the contaminants [6]. The design and optimization of a PEMFC system are very complex because they are related to the use of the system, the selection of appropriate components, and the functions of each variable. The purpose of studies on PEM fuel cell systems is to consider the capital and operational costs, efficiency, fuel consumption, flexibility and fuel cell life [7-10]. Other parameters such as the pressure, temperature, composition and utilization of the fuel, and composition and the utilization of oxidant can be varied simultaneously to achieve the desired operating point.

The main challenges facing the commercialization of PEM fuel cells include cost and reliability PEM fuel cell characteristics are highly influenced by the design of an optimal PEMFC system. The PEM fuel cell central system must be supported by providing an oxidant supply (oxygen or air), a fuel supply (hydrogen), heat and water management, process control, equipment and supervision [11-12]. The many failures in PEM fuel cell systems include flooding, the diffusion of water from the cathode side to the anode side and poor of integration heat and mass management during the operation of the system [13-15]. The focus of this research was to develop a fundamental thermodynamic basis for developing a modeling system to optimize the performance of PEM fuel cell systems. The next focus was to determine the relative humidity of the reactants entering the PEM fuel cell stack on the voltage and the current density that was produced by the resulting fuel cell system.

\footnotetext{
*Corresponding author: mulyazmi@y ahoo.com
} 


\section{RESEARCH DESIGN}

This research design is to determine the performance of a single cell PEM fuel cell based on the process performed by mulyaznmi 2013 [16]. Single cell Of PEM fuel cell performance produced using an assumed reactant has passed the external humidifier.The determination of single cell of PEM fuel cell performance was determined by variating relative humidity on the anode and cathode sides, as well as validating results obtained from other studies.The operating parameters used as the basis for the modeling case are listed in Table 1.

Table 1. Basic modeling operation parameters

\begin{tabular}{ll}
\hline Parameters & Value \\
\hline Cell Temperature & 353 \\
Thick dry membrane & $0.0051 \mathrm{~cm}$ for Nafion \\
& 112 \\
Cataly st load & $0.0002 \mathrm{~g} \mathrm{~cm}^{-2}$ \\
Thick catalyst & $0.0005 \mathrm{~cm}$ \\
Faraday Constant & $96,485 \mathrm{C} / \mathrm{mol}$ elektron \\
Stoikhiometric ratio for & 1.2 \\
hydrogen & \\
Stoichiometric ratio for oxy gen & 2 \\
Universal gas constant & $8.314 \mathrm{~J} / \mathrm{mol} \mathrm{K}$ \\
\hline
\end{tabular}

\section{Mathematics Models}

The reaction that occurs in the PEM fuel cell system is:

Anode: $\quad \mathrm{H}_{2} \rightarrow 2 \mathrm{H}^{+}+2 \mathrm{e}^{-}$

Chatode: $1 / 2 \mathrm{O}_{2}+2 \mathrm{H}^{+}+2 \mathrm{e}^{-} \rightarrow \mathrm{H}_{2} \mathrm{O}$

Overall: $\mathrm{H}_{2 \text { (gas) }}+1 / 2 \mathrm{O}_{2 \text { (gas) }} \rightarrow \mathrm{H}_{2} \mathrm{O}+$ heat + electric

\subsection{Water Liquid in the reactant}

The water vapor component with hydrogen as a reactant flowing in the PEM fuel cell is (Barbier, F. 2005):

$$
\mathcal{N}_{\mathrm{H}_{2} \mathrm{OinH}_{2}}=\frac{\mathcal{S}_{\mathrm{H}_{2} \cdot I}}{2 \mathrm{~F}} \cdot \eta_{\text {cell }} \cdot y
$$

The molar humidity ratio of $y \mathrm{y}$ is as follows::

$$
y=\frac{\mathcal{N}_{v}}{\mathcal{N}_{a}}=\frac{\text { mol of water vapor }}{\text { mol of dry gas }}
$$

The mass and molar relation of humidity is

$$
y \frac{M_{v}}{M_{a}}=x
$$

Mole fraction of water vapor can be interpreted as follows[17]:

$$
y=\varphi \frac{P_{\text {sat }}}{P}
$$

$\varphi$ is relative humidity, $P_{s a t}$ is saturated vaporpressure (atm), and $P$ is total pressure (atm).

The saturated vapor pressure $p_{H 2 O}$ is as follows [18]:

$$
\begin{array}{rl}
P_{\mathrm{H}_{2} O}^{o}(T)=6.02 & 24 \\
& +4.38484 \times 10^{-4}(T-273.15) \\
& +1.39844 \times 10^{-5}(T-273.25)^{2} \\
& +2.71166 \times 10^{-7}(T-273.15)^{3} \\
& +2.57731 \times 10^{-9}(T-273.15)^{4} \\
& +2.82254 \times 10^{-11}(T-273.15)^{5}
\end{array}
$$

The molar ratio relationship $y$ with partial pressure is::

$$
y=\frac{P_{v}}{P_{a}}=\frac{P_{v}}{P-P_{v}}
$$

$P_{v}$ is partial pressure of water vapor (atm), $P_{a}$ is partial pressure gas (atm), $P$ is total pressure.

Based on equation (6), then:

$$
y=\frac{x \cdot M_{a}}{M_{w}}
$$

Then the equation becomes

Consequently:

$$
\frac{P_{v}}{P-P_{v}}=\frac{x \cdot M_{a}}{M_{w}}
$$

$$
y=\frac{\varphi \cdot P_{V_{S}}}{P-\varphi \cdot P_{V_{S}}}
$$

So the amount of moles of water vapor in hydrogen is:

$$
\mathcal{N}_{\mathrm{H}_{2} \mathrm{O} . \text { in } \mathrm{H}_{2}}=\frac{\mathcal{S}_{\mathrm{H}_{2} \cdot I}}{2 \mathrm{~F}} \cdot \eta_{\text {cell }} \cdot \frac{\varphi \cdot P_{V_{S}}}{P-\varphi \cdot P_{V_{S}}}
$$

where: $P_{a}$ is the steam flow pressure in the hydrogen flowing into the anode. While the amount of water vapor in oxygen flowing in PEM fuel cell is:

$\mathcal{N}_{\mathrm{H}_{2} \mathrm{O} \text {, in } \mathrm{O}_{2}}=\mathcal{S}_{\mathrm{O}_{2}} \cdot \mathcal{N}_{\mathrm{O}_{2}} \cdot \eta_{\text {cell }} \frac{\varphi \cdot P_{V_{S}}}{P_{c}-\varphi \cdot P_{V_{S}}}$

Where $P_{c}$ is the pressure of the water vapor flow in oxygen flows into the anode. The amount of water vapor in the air flowing in PEM fuel cell is:

$\mathcal{N}_{\mathrm{H}_{2} \text { O, in air }}=\mathcal{S}_{\mathrm{O}_{2}} \cdot n_{\text {cell }} \frac{\mathcal{N}_{\mathrm{O}_{2}}}{X O_{2}} \frac{\varphi \cdot P_{V_{S}}}{P_{c}-\varphi \cdot P_{V_{S}}}$

The mass of air flowing out of PEM fuel cell is:

$\mathcal{N}_{\text {air , out steack }}=\left\lfloor\left(\mathcal{S}_{\mathrm{O}_{2}} \frac{1-\mathrm{XmolO}_{2}}{\mathrm{XmolO}_{2}}\right)+\left(\mathcal{S}_{\mathrm{O}_{2}}-1\right)\right\rfloor \frac{I}{4 F} n_{\text {cell }}$

\subsection{EOD and Back Diffusion}

The number of protons that move from the anode to the cathode of the PEM fuel cell $\left(\mathcal{N}_{\text {drag }}\right)$ on the EOD phenomenon can be calculated based on the following equations [19-21]:

$$
\mathcal{N}_{\text {drag }}=\frac{n_{d}}{F} I
$$

EOD coefficient value $\left(n_{d}\right)$ can be defined based on the following equation:

$$
n_{d}=\frac{2.5 \lambda p e m}{22}
$$

Where $\lambda$ pem is the membrane water content that can be calculated based on the following equation [22-24]:

$$
\begin{aligned}
\lambda=0.043+17.81 a_{H 2 O}-39.85 & a_{H 2 O}^{2} \\
& +36 . a_{H 2 O}^{3} \quad 0<a_{H 2 O} \leq 1
\end{aligned}
$$

Membrane water activity $a_{H 2 O}$ is calculated based on the following equation

$$
a_{\mathrm{H} 2 \mathrm{O}}=\frac{a_{\mathrm{H} 2 \mathrm{O}, a+a_{\mathrm{H} 2 \mathrm{O}, k}}}{2}
$$

Water diffusion from the cathode side to the anode side PEM fuel cell $\mathcal{N}_{\text {diff,H20 }}$ is defined as follows [20, 22, 25]:

$$
\mathcal{N}_{\text {diff }, H 20}=D_{w} \frac{\left(C_{K, v-}-C_{A, v}\right)}{x_{m}}
$$

According to [17] that the water diffusion from the anode side to the cathode side of the PEM fuel cell system is as follows:

$$
J_{w}=k_{g}\left(y_{a}-y_{c}\right)
$$

$J_{w}$ is humidity flux across the membrane 


\subsection{PEM Fuel Cell Performance}

The value of cell voltage at PEMFC system is [26]

$$
\begin{gathered}
V_{\text {operasi }}=V_{\text {rev }}-V_{\text {irrev }} \\
V_{\text {irrev }}=V_{\text {act }}-V_{\text {ohm }}-V_{\text {con }}
\end{gathered}
$$

\subsubsection{Reversible Cell Voltage $\left(V_{\text {rev }}\right)$}

At standard state the value of PEM fuel cell electric power is [27]:

$E=\frac{-\Delta G_{f}^{o}}{n F}=\frac{237.340}{2 \text { molx } 96,485} \frac{\mathrm{Kjmol}^{-1}}{\mathrm{Cmol}^{-1}}=1.229 \mathrm{~V}$ At $25^{\circ} \mathrm{C}$ and pressure $1 \mathrm{~atm}$

The potential of electricity as a function of temperature $\left(E_{T}\right)$ is:

$$
E_{T}=E^{0}+\frac{\Delta S}{n F}\left(T-T_{0}\right)
$$

The reversible voltage for PEM fuel cell is [27-29]:

$$
V_{\text {rev }}=E_{T}+\frac{R T}{n F} \ln \left(\frac{P_{\mathrm{H}_{2} x\left(P_{O_{2}}{ }^{0.5}\right)}}{P_{\mathrm{H}_{2} \mathrm{O}} \mathrm{O}}\right)
$$

So the value of PEM fuel cell electric power based on equation (22) is:

$E_{T}=1.229 \mathrm{~V}-0.85 \times 10^{-3}\left(T-T_{0}\right) \mathrm{V} / K(24)$

Assuming that the partial pressure is $1 \mathrm{~atm}$ because the water is in the liquid phase, then:

$$
\begin{aligned}
V_{\text {rev }}=1.229 \mathrm{~V}- & 0.85 \times 10^{-3}\left(\mathrm{~T}-\mathrm{T}_{0}\right) \\
& +4.31 \times 10^{-5} \times \mathrm{T} x \ln \left(P_{\mathrm{H}_{2}} x\left(P_{\mathrm{O}_{2}}{ }^{0.5}\right)\right)
\end{aligned}
$$

\subsubsection{Voltage Activation $\left(\mathrm{V}_{\mathrm{act}}\right)$}

In the equilibrium state, the net current (zero down stream) is zero, although the PEMFC response system occurs simultaneously. The consequences are:

$$
r=k_{f} C_{O_{2}}-k_{b} C_{H_{2}}=\frac{i_{c}}{n F}-\frac{i_{a}}{n F}
$$

The value is expressed as a change in the current density. This condition can be stated as follows:

$$
i_{c}=i_{a} \text { danr }_{f}=r_{b}
$$

Can be simplified to be the first form:

$$
\frac{R T}{F}\left[\frac{d}{d E} \ln \left(k_{b}\right)-\frac{d}{d E} \ln \left(\frac{1}{k_{f}}\right)\right]=1
$$

For the reductive symmetry factor expressed by $\alpha$, then

$$
\frac{R T}{F} \frac{d}{d E} \ln \left(\frac{1}{k_{f}}\right)=\alpha
$$

With oxidative symmetry is: $1-\alpha$

$$
\frac{R T}{F} \frac{d}{d E} \ln \left(k_{b}\right)=1-\alpha
$$

Can be simplified to:

$$
\ln \left(k_{b}\right)=\frac{(1-\alpha) \mathrm{FE}}{\mathrm{RT}}+\mathrm{c}
$$

$k_{f}$ value for standard condition is $k_{f}=k_{f, 0}, k_{b}=k_{b, 0}$ and $E=E_{0}$

Can be changed to:

$$
\begin{aligned}
& k_{f}=k_{f, 0} \exp \left(\frac{-\alpha \mathrm{FE}}{\mathrm{RT}}\right) \\
\text { And } \quad k_{b}= & k_{b, 0} \exp \left(\frac{(1-\alpha) \mathrm{FE}}{\mathrm{RT}}\right)
\end{aligned}
$$

Then known as the Butler Volmer equation, then the rate of reaction in the cell is:

$$
\begin{aligned}
i=n F\left(k_{f, 0} \exp \left(\frac{-\alpha \mathrm{FE}}{\mathrm{RT}}\right) C_{O_{2}}\right. \\
\left.-k_{b, 0} \exp \left(\frac{(1-\alpha) \mathrm{FE}}{\mathrm{RT}}\right) C_{\mathrm{H}_{2}}\right)
\end{aligned}
$$

In equilibrium condition it is assumed that $k_{f, 0}=k_{b, 0}=$ $k_{0}$

$$
i_{0}=n F k_{0} C_{O_{2}}{ }^{(1-\alpha)} C_{H_{2}}{ }^{\alpha}
$$

If this equation is compared to the reference current density $\left(i_{0, r e f}\right)$ is:

$i_{0}=i_{0, \text { ref }}\left({\frac{P_{R}}{P_{R, r e f}}}^{\gamma}\right) \exp \frac{E_{C}}{R T}\left(1-\frac{T}{T_{\text {ref }}}\right)$

The $i_{0}$ value is detected by the ideal surface reaction area per unit volume of the catalyst layer $(a)$ [30-32]

The equation becomes:

$i_{0}=a i_{0, \text { ref }}\left({\frac{P_{R}}{P_{R, \text { ref }}}}^{\gamma}\right) \exp \frac{E_{c}}{R T}\left(1-\frac{T}{T_{\text {ref }}}\right)$

$E_{c}=76.5 \mathrm{Kj} / \mathrm{mol}[33]$

According to [31] that the value of $a$ a is:

$a=a_{0} \frac{m_{p t}}{L}$

According to [34] the value of $a_{0}$ is:

$$
\begin{aligned}
a_{0}=10^{8}(4.4198 & Y^{9}-27.691 Y^{8}+74.206 Y^{7} \\
& -111.06 Y^{6}+101.43 Y^{5}-57.841 Y^{4} \\
& \left.+20.231 Y^{3}-4.089 Y^{2}+0.39451 Y\right)
\end{aligned}
$$

WithY $=\% \mathrm{Pt}$ catalysts having value in the range 0 to $100 \%$.

$$
\begin{aligned}
a_{0}=10^{8}(4.4198 & Y^{9}-27.691 Y^{8}+74.206 Y^{7} \\
& -111.06 Y^{6}+101.43 Y^{5}-57.841 Y^{4} \\
& \left.+20.231 Y^{3}-4.089 Y^{2}+0.39451 Y\right)
\end{aligned}
$$

According to [35] and [31] the reference current density value is:

$$
i_{0, r e f}=10^{\left(3.057-\frac{4001}{T}\right)}
$$

The value of the current density based on equation is::

$$
i=n F k_{0}\left(C_{O_{2}} \exp \left(\frac{-\alpha \mathrm{FE}}{\mathrm{RT}}\right)-C_{\mathrm{H}_{2}} \exp \left(\frac{(1-\alpha) \mathrm{FE}}{\mathrm{RT}}\right)\right)
$$

If the value $i \mathrm{i}$ compared $i_{0}$ to the equation (35) is:

$\frac{i}{i_{0}}=\frac{n F k_{0}\left(C_{O_{2}} \exp \left(\frac{-\alpha \mathrm{FE}}{\mathrm{RT}}\right)-C_{\mathrm{H}_{2}} \exp \left(\frac{(1-\alpha) \mathrm{FE}}{\mathrm{RT}}\right)\right)}{n F k_{0}\left(c_{O_{2}} \exp \left(\frac{-\alpha \mathrm{FE}}{\mathrm{RT}}\right)\right)}$

Nilai $\mathrm{E}-\mathrm{E}_{\mathrm{r}}=\eta_{\text {act }}$, maka nilai $\frac{i}{i_{0}}$ menjadi:

$$
\mathrm{V}_{\mathrm{act}}=\frac{\mathrm{RT}}{2 \alpha F} \sinh ^{-1}\left(\frac{i}{i_{0}}\right)
$$

The activation voltage value is [36-37]:

$$
V_{\text {act }}=\frac{R T}{n \alpha F} \ln \left(\frac{i}{i_{0}}\right) \text { wherei }>i_{0}
$$

According to [36] the value of $i_{0}$ depends on temperature, pressure, type of catalyst used, specific surface area and loading. The value of $i_{0}$ is $10^{-2} \mathrm{~A}$ to $10^{-8}$ A. Based on the equation (42), the value of Tafel constant is::

$$
b=\frac{R T}{n \alpha F}
$$

In the PEMFC system model design, the Tafel constant value is based on research data conducted by [38]is: 


$$
b=0.1937 e^{-2.197(\alpha)}
$$

$\alpha$ is the exchange coefficient, whose value is [18]:

$\alpha=\left(0.001552 R H_{c, \text { inlet }}+0.000139\right) T$

$R H_{c, \text { inlet }}$ is the relative humidity that flows into the cathode of PEM fuel cell

\subsubsection{Voltage Ohm $\left(\mathrm{V}_{\mathrm{ohm}}\right)$}

Loss caused by ohm resistance occurs in the membrane and catalyst layer and is a function of temperature and humidity [39]. Total voltage loss in PEM fuel cell is a linear function [40]. The total value of the ohm voltage according to [37] is:

$$
V_{o h m}=i R_{o h m}
$$

While the value of $R_{\text {ohm }}$ :

$$
R_{\text {ohm }}=\frac{t_{m}}{\sigma_{m}}
$$

The value of the membrane conductivity is $[32,41]$ : $\sigma_{m}=\left(0.005139 \lambda_{m}\right.$

$$
-0.003260) \exp \left[1268\left(\frac{1}{303}-\frac{1}{T}\right)\right]
$$

The value of the membrane water content is:

$$
\lambda_{m}=0.048+17.81 R H-39.83 R H^{2}+39.85 R H^{3}
$$

$a$ is the average relative humidity in the PEM fuel cell steck..

\subsubsection{Concentric Voltage Kepekatan $\left(V_{\text {conc }}\right)$}

Loss of concentration capability because the reaction of the electrode is restricted by the reactant mass transfer within the PEM ful cell [40]. The concentration capability value [29] is:

$$
V_{\text {conc }}=\operatorname{cln}\left(\frac{i_{L}}{i_{L}-1}\right)
$$

$c$ is the constant of loss by concentration. The value of $c$ is:

$$
\begin{array}{r}
c=\frac{R T}{n F} \\
V_{\text {conc }}=\frac{R T}{n F} \ln \left(\frac{i_{L}}{i_{L}-1}\right)
\end{array}
$$

$i_{L}$ is the maximum value of the current density generated by PEM fuel cell. The amount of current density limit value by the PEMfuel cell is [42]

$$
i_{L}=n F h_{m}\left(\frac{{ }^{{ }_{0}, \text { in }}-c_{O_{2, \text { out }}}}{\ln \frac{{ }^{O_{2, \text { in }}}}{{ }^{O_{2, \text { out }}}}}\right)
$$

$c_{O_{2, \text { indanout }}}$ is the concentration of oxygen flowing in and out of PEM fuel cell (mol)

$h_{m}$ is the convective mass transfer coefficient. The convective mass transfer coefficient value by [43]:

$$
h_{m}=\frac{S h_{f} D_{i j}}{H_{c}}
$$

\section{ResultS and Discussion}

Figure 2 shows the effect that relative humidity has on the single cell performance. The operating temperature was maintained at $353 \mathrm{~K}$. The pressure at the anode and the cathode was 1atm. The hydrogen to oxygen stoichiometric ratio was 1.2 for hydrogen and 2 for oxygen. An increased RHA and an increased RHC value generally improve the single cell performance, as shown by the increases in the voltage and the power density that are produced. The single cell performance can be improved by increasing the relative humidity at the cathode, which increases the voltage and the power density that are produced. This result is reflected by the increased voltage and power density that are produced. Higher single cell performance can be achieved by increasing the RHC value.

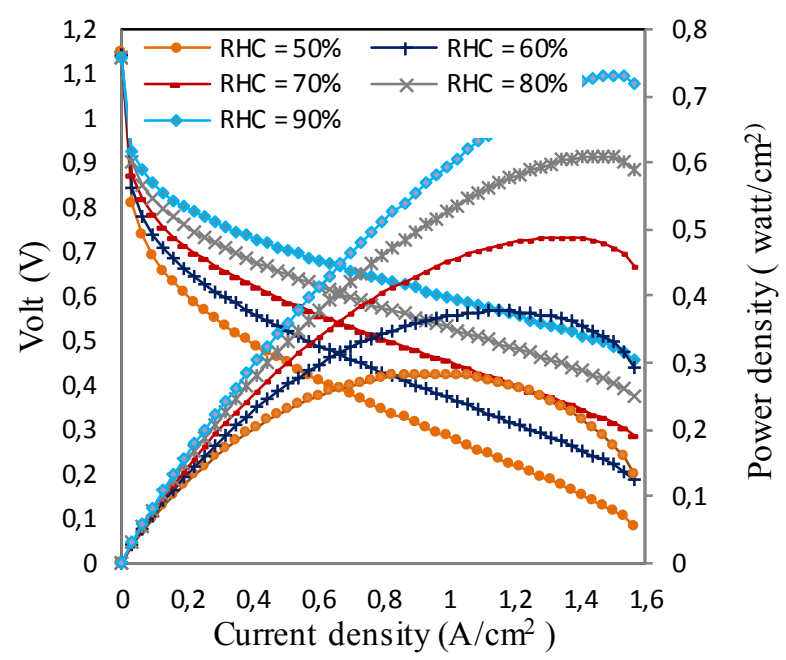

(a)

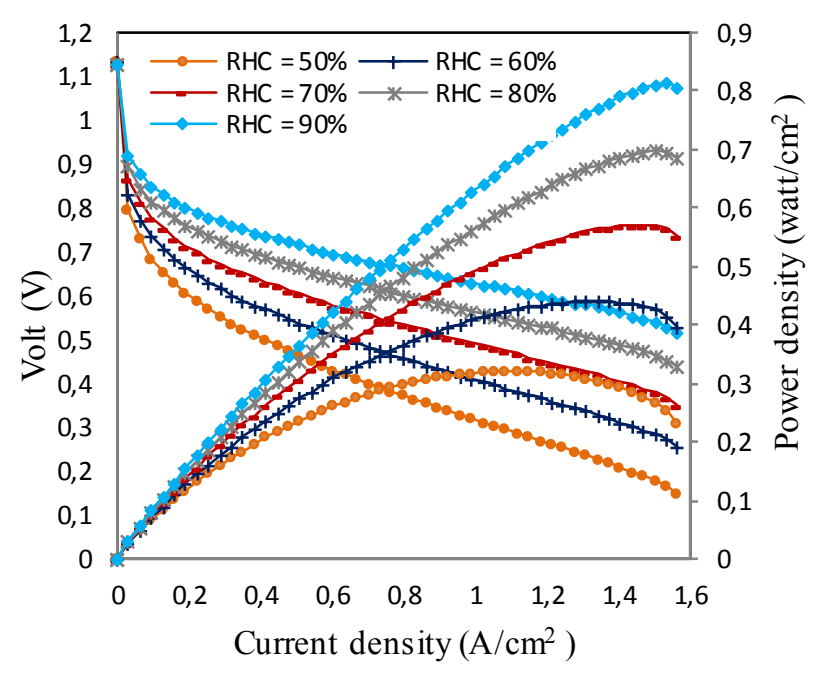

(b) 


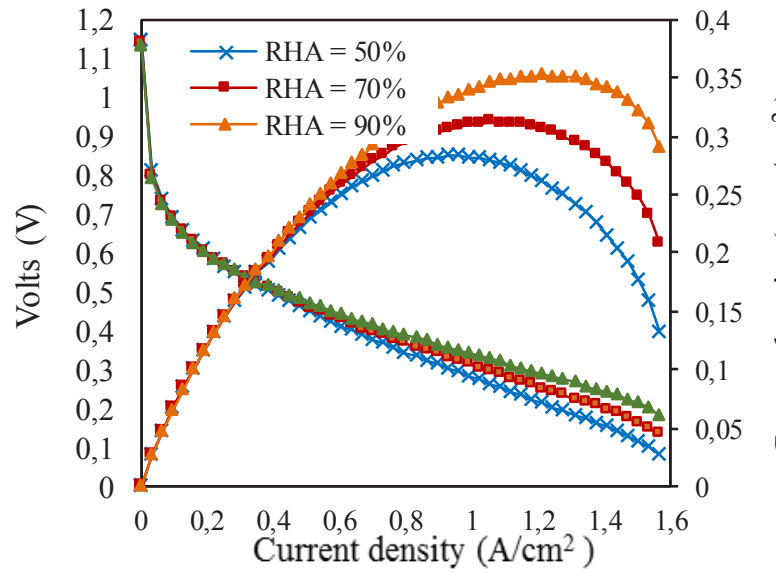

(c)

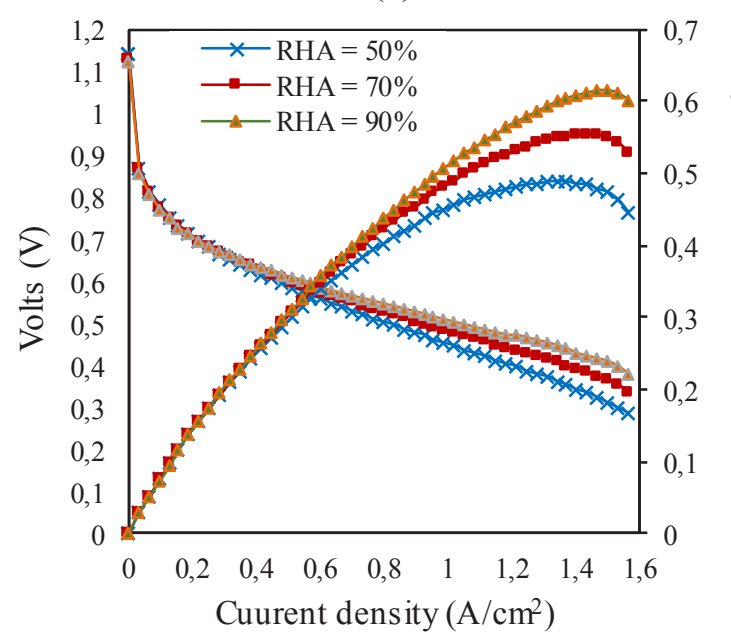

(d)

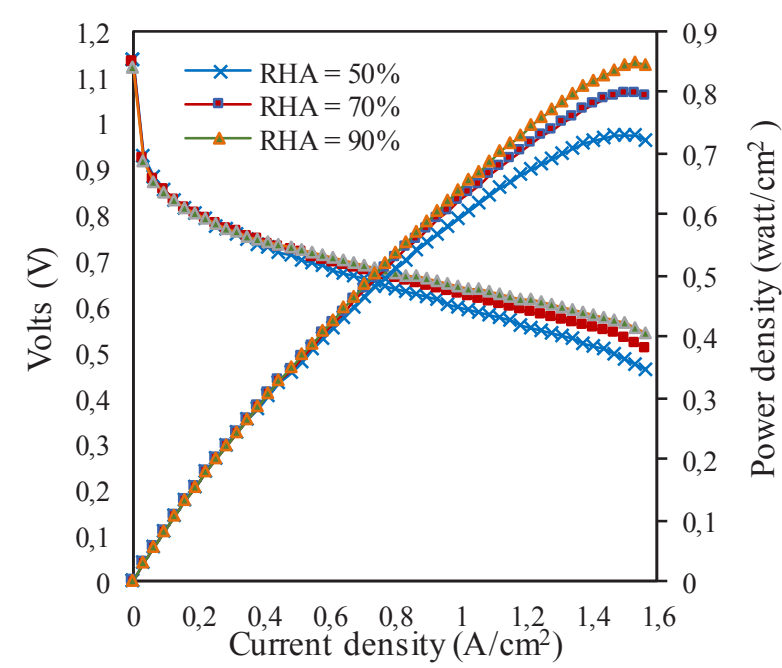

(e)

Fig 2. Effect of relative humidity on single cell performance of PEM fuel cells at temperatures of $353 \mathrm{~K}$, the operating pressure of $1 \mathrm{~atm}$, the stoichiometric ratio is 1.2 for $\mathrm{H} 2$ and $\mathrm{O} 2$ are 2: (a) RHA is $50 \%$ and RHC are $50 \%, 60 \%, 70 \%, 80 \%$ and $90 \%$. (b) RHA is $75 \%$ and RHA are $50 \%, 60 \%, 70 \%, 80 \%$ and $90 \%$. (c) RHA is $50 \%, 70 \%$ and $90 \%$, RHC is $50 \%$. (d) RHA are $50 \%$, $70 \%$ and $90 \%$, RHC is $70 \%$. (e) RHA are $50 \%, 70 \%$ and $90 \%$, RHC is $90 \%$.
Figures $2 \mathrm{a}$ and $2 \mathrm{c}$ show the effects of varying the relative humidity while all the other conditions are kept constant. The RHA in Figure 2a was maintained at $50 \%$ while the RHC was varied from $50 \%$ to $90 \%$. In figure $2 \mathrm{c}$, the RHC was maintained at 50\% while the RHA was varied from $50 \%$ to $90 \%$. Figure $2 \mathrm{a}$ shows the improvement in the single cell performance with an increase in the RHA. Figure 2c shows that the increase in RHA causes an insignificant improvement in the single-cell performance. Increasing the RHC was more effective than increasing the RHA with regard to improving the single cell performance. The increases in the RHA and the RHC resulted in an increased voltage and an increased power density. Specifically, an increased RHC significantly improved single cell performance. Figures $2 c, 2 d$ and $2 e$ show the effect of RHA on the single cell performance; improved performance occurs beyond a voltage of $0.6 \mathrm{~V}$. Figures $2 \mathrm{a}$ and $2 \mathrm{~b}$ show the effect of maintaining the RHA at $50 \%$ and $70 \%$ while the value of RHC was kept constant from $50 \%$ to $90 \%$.

The current density of a single PEM fuel cell at a voltage of $0.6 \mathrm{~V}$ is shown in table 2 .

Table 2. PEM fuel cell performance at $0.6 \mathrm{~V}$ with different relative humidity at the cathode

\begin{tabular}{|c|c|c|c|c|c|}
\hline \multirow[t]{3}{*}{ Condition } & \multicolumn{5}{|c|}{$\begin{array}{l}\text { Current density }\left(\mathrm{A} \mathrm{cm}^{-2}\right) \text { at } 0.6 \mathrm{~V} \text { with } \\
\text { different relative humidity at the cathode }\end{array}$} \\
\hline & RHC & RHC & RHC & RHC & RHC \\
\hline & $50 \%$ & $60 \%$ & $70 \%$ & $80 \%$ & $90 \%$ \\
\hline Condition 1 & 0.193 & 0.289 & 0.449 & 0.673 & 0.961 \\
\hline Condition 2 & 0.193 & 0.321 & 0.513 & 0.801 & 1.185 \\
\hline
\end{tabular}

Note:

Condition 4: $\mathrm{RHA}=50 \%, \mathrm{PA}$ and $\mathrm{PC}=1 \mathrm{~atm}$ and $\mathrm{T}=353 \mathrm{~K}$ Condition 5: $\mathrm{RHA}=75 \%, \mathrm{PA}$ and $\mathrm{PC}=1 \mathrm{~atm}$ and $\mathrm{T}=353 \mathrm{~K}$

Conditions 1 and 2 in table 2 show that the single PEM fuel cell was able to maintain the current density at the same value when the RHC was $50 \%$, even though the RHA was increased from $50 \%$ to $70 \%$. The current density increased when the RHC was increased from $60 \%$ to $90 \%$. The same effect was observed when the RHA was increased from $50 \%$ to $70 \%$, which resulted in an increased current density at a voltage of $0.6 \mathrm{~V}$.

Table 3. . PEM fuel cell performance at $0.6 \mathrm{~V}$ with different relative humidity at the anode

\begin{tabular}{cccc}
\hline \multirow{2}{*}{ Condition } & \multicolumn{3}{c}{ Current density $\left(\mathbf{A ~ c m}^{-2}\right)$ at $\mathbf{0 . 6 V}$ with } \\
& different relative humidity at the anode \\
\cline { 2 - 4 } & RHA 50\% & RHA 70\% & RHA 90\% \\
\hline Condition 3 & 0.193 & 0.193 & 0.193 \\
Condition 4 & 0.449 & 0.513 & 0.545 \\
Condition 5 & 0.961 & 1.121 & 1.281 \\
\hline
\end{tabular}

Note:

Condition $3: \mathrm{RHC}=50 \%, \mathrm{PA}$ and $\mathrm{PC}=1 \mathrm{~atm}$ and $\mathrm{T}=353 \mathrm{~K}$ Condition $4: \mathrm{RHC}=75 \%, \mathrm{PA}$ and $\mathrm{PC}=1$ atm and $\mathrm{T}=353 \mathrm{~K}$ Condition $5: \mathrm{RHC}=90 \%, \mathrm{PA}$ and $\mathrm{PC}=1 \mathrm{~atm}$ and $\mathrm{T}=353 \mathrm{~K}$ 


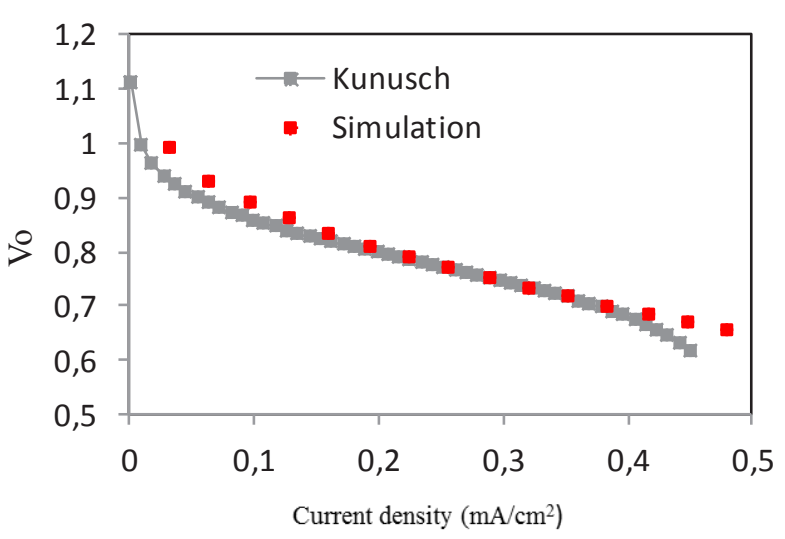

Fig 3. validation of simulation results

Table 3 shows the current density at a voltage of $0.6 \mathrm{~V}$ when the RHA was varied. When the cell was operated at Condition 3, an increase in the RHA from $50 \%$ to $90 \%$ did not affect the value of current density at $0.193 \mathrm{~A} \mathrm{~cm}^{-}$ 2. However, Conditions 7 and 8 show that an increase in the RHC and the RHA result in an increased current density in the single cell. Tables 3 and 3 show that when the RHC was $50 \%$ and the RHA was $50 \%$ in Conditions 1,2 and 3 , the current density remained unchanged at $0.193 \mathrm{Acm}^{-2}$. The increase in the RHA did not significantly increase the current density. However, an increase in the RHC significantly increased the current density. The performance of the single cell was highest at RHC values ranging from $70 \%$ to $90 \%$.

The results of the simulation study in figure 3 showed similar trends in the performance of a single cell PEM fuel cell. However, the simulation results in this study did not show a significant decrease in voltage over the current density of $0.45 \mathrm{~A} \mathrm{~cm}^{2}$, while the simulation results performed by Khunush showed a decrease in voltage value. The decrease in the value of this voltage is due to insufficient hydrogen and oxygen for the reaction

\section{Conclusion}

The conclusions that can be drawn from this study are as follows:

1.In the same relative humidity value at one side of the PEM Fuel Cell, the increase in single cell performance is influenced by the increase in RHC value compared to RHA value.

2. The highest single cell performance that occurs at $0.6 \mathrm{~V}$ is indicated by the RHA value from $70 \%$ to $90 \%$ and $\mathrm{RHC}$ is $90 \%$.

\section{Acknowledgement}

The authors would like to thanks the Bung Hatta University (UBH) and RISTEK DIKTI supporting this project through PUPT 2017 research grant. And also thanks to Axel Okta Yuga and Devani Adristi.

\section{References}


field," Journal of Power Sources, vol. 162, pp 1157-1164, 2006.

[16] Mulyazmi, et al., "Water balance for the design of a PEM fuel cell system," International Journal of Hydrogen Energy, vol. 38, pp. 9409-9420, 2013.

[17] N. S. M. Hassan, et al., "Water management in a single cell proton exchange membrane fuel cells with a serpentine flow field," Journal of Power Sources, vol. 193, pp. 249257, 2009.

[18] J. Zhang, et al., "PEM fuel cell relative humidity (RH) and its effect on performance at high temperatures," Electrochimica Acta, vol. 53, pp. 5315-5321, 2008.

[19] B. Zhou, et al., "Water and pressure effects on a single PEM fuel cell," Journal of Power Sources, vol. 155, pp. 190-202, 2006.

[20] Y. Zong, et al., "Water and thermal management in a single PEM fuel cell with non-uniform stack temperature," Journal of Power Sources, vol. 161, pp. 143-159, 2006.

[21] X. Yu, et al., "Water and thermal management for Ballard PEM fuel cell stack," Journal of Power Sources, vol. 147, pp. 184-195, 2005.

[22] F. Gao, et al., "Proton exchange membrane fuel cell multi-physical dynamics and stack spatial non-homogeneity analyses," Journal of Power Sources, vol. 195, pp. 7609-7626, 2010.

[23] K. Chu, et al., "A lumped parameter model of the polymer electrolyte fuel cell," Journal of Power Sources, vol. 171, pp. 412-423, 2007.

[24] S. A. J. Erahim Afshari, "Heat and Water Management in a PEM Fuel Cell," Wseas Tctions on Flui Mechanic, vol. 3, p. 6, 1998.

[25] A. J. del Real, et al., "Development and experimental validation of a PEM fuel cell dynamic model," Journal of Power Sources, vol. 173, pp. 310-324, 2007.

[26] S. O. Mert, et al., "Performance investigation of a transportation PEM fuel cell system," International Journal of Hydrogen Energy, vol. 37, pp. 623-633, 2012.

[27] Y.-S. Chen and H. Peng, "A segmented model for studying water transport in a PEMFC," Journal of Power Sources, vol. 185, pp. 11791192, 2008.

[28] L. Placca, et al., "Effects of temperature uncertainty on the performance of a degrading PEM fuel cell model," Journal of Power Sources, vol. 194, pp. 313-327, 2009.

[29] H. Shaker, "Analytical modeling of PEM fuel cell i-V curve," Renewable Energy, vol. 36, pp. 451-458, 2011.

[30] T. Thampan, et al., "PEM fuel cell as a membrane reactor," Catalysis Today, vol. 67, pp. 15-32, 2001.

[31] D. Song, et al., "Numerical optimization study of the catalyst layer of PEM fuel cell cathode," Journal of Power Sources, vol. 126, pp. 104-111, 2004.
Y. Shan and S.-Y. Choe, "A high dynamic PEM fuel cell model with temperature effects," Journal of Power Sources, vol. 145, pp. 30-39, 2005.

[33] B. A. P. Wei Suna, Kunal Karana, "An improved two-dimensional agglomerate cathode model to study the influence of catalyst layer structural parameters " Electrochemica Acta, vol. 50, p. 16, 2005.

[34] D. Song, et al., "A method for optimizing distributions of Nafion and $\mathrm{Pt}$ in cathode catalyst layers of PEM fuel cells," Electrochimica Acta, vol. 50, pp. 3347-3358, 2005.

[35] G. Inoue, et al., "Evaluation of the optimal separator shape with reaction and flow analysis of polymer electrolyte fuel cell," Journal of Power Sources, vol. 154, pp. 18-34, 2006.

[36] H. Görgün, et al., "An algorithm for estimation of membrane water content in PEM fuel cells," Journal of Power Sources, vol. 157, pp. 389-394, 2006.

[37] C. Kunusch, et al., "Characterization and experimental results in PEM fuel cell electrical behaviour," International Journal of Hydrogen Energy, vol. 35, pp. 5876-5881, 2010.

[38] R. F. Mann, et al., "Application of ButlerVolmer equations in the modelling of activation polarization for PEM fuel cells," Journal of Power Sources, vol. 161, pp. 775781, 2006.

[39] K. Scott and M. Mamlouk, "A cell voltage equation for an intermediate temperature proton exchange membrane fuel cell," International Journal of Hydrogen Energy, vol. 34, pp. 9195-9202, 2009.

[40] B. Abdellah, "Modeling and simulation of proton exchange membrane fuel cell systems," Journal of Power Sources, vol. 205, pp. 335-339, 2012.

[41] X. Zhang, et al., "The parametric optimum analysis of a proton exchange membrane (PEM) fuel cell and its load matching," Energy, vol. 35, pp. 5294-5299, 2010.

[42] C. Spiegel, "PEM Fuel Cell Modeling and Simulation Using MATLAB," Elsevier Inc, 2008.

[43] R. R. B. Tavakoli, "The effect of fuel cell operational conditions on the water content distribution in the polymer electrolyte membrane," Renewable Energy, vol. XXX, p. $13,2011$. 